\title{
Serum Insulin-Like Growth Factor 1 and Serum Growth-Promoting Activity during the First Postnatal Year in Infants with Intrauterine Growth Retardation
}

\author{
G. THIERIOT-PREVOST, J. F. BOCCARA, C. FRANCOUAL, J. BADOUAL, AND J. C. JOB \\ INSERM U 188 and Unités de Pédiatrie Néonatale, Hôpital Saint-Vincent-de-Paul, Paris, France
}

\begin{abstract}
Follow-up from birth to age 12 months was obtained in 21 infants born with intrauterine growth retardation. Serum insulin-like growth factor 1 was measured by radioimmunoassay. The bioassayable growth-promoting activity of the serum was measured as the "thymidine activity" on lectin-activated lymphocytes at 5 days and 1 , $3,6,9$, and 12 months, and was compared with control values. Depending on their length at age 12 months, the intrauterine growth retardation infants were divided into three groups: at or above the average $(n=8$, group $A)$, between the mean and -2 SD $(n=7$, group B), or less than $-2 \mathrm{SD}(n=6$, group $C)$. No differences in nutritional indexes or in head circumference were found between the three groups. Insulin-like growth factor 1 was significantly lower at age 5 days in intrauterine growth retardation than in control infants. It increased slowly in groups $A$ and $B$ to reach the control values at age 9 and 12 months. In group $\mathrm{C}$ it remained significantly subnormal at $1 \mathrm{yr}$ of age. Thymidine activity was also significantly lower at age 5 days in intrauterine growth retardation compared with control infants. It increased sharply at age 1-3 months in groups $A$ and $B$ but remained significantly lower in group $C$ up to 1 yr of age. Although individual values of insulinlike growth factor 1 and thymidine activity were closely correlated, the increase of length during the first postnatal year correlated significantly with the thymidine activity levels at 1 and 3 months but not with the insulin-like growth factor 1 levels at 1, 3, and 6 months. These data may be of some physiological significance for understanding the postnatal catch-up growth occurring after intrauterine growth retardation. (Pediatr Res 24: 380-383, 1988)
\end{abstract}

\section{Abbreviations}

IGF 1, insulin-like growth factor 1

TA, thymidine activity of serum

IUGR, intra-uterine growth retardation

SFD, small-for-dates newborns

SGA, small for gestational age newborns

AGA, appropriate for gestational age newborns

The early growth of children born with IUGR, or who were SFD, has been carefully studied by several authors (1-9). The main emphasis of these reports has been on the catch-up growth

Received March 9, 1988; accepted May 24, 1988. Correspondence Dr. J. C. Job, Hôspital Saint-Vincent-de-Paul, 74 Avenue Denfert Rochereau, 75014 Paris, France. that occurs in most but not all IUGR infants, usually in early postnatal life. The predictive value of various prenatal and neonatal parameters has been extensively discussed. However, although several studies have shown that somatomedin C/IGF 1 levels are lower in SFD than in normal-for-dates newborns (1013), no longitudinal data on serum IGF 1 values in IUGR infants have been reported. The aim of this study was to follow the evolution of serum IGF 1 measured by radioimmunoassay and of the serum growth-promoting activity measured using a previously published bioassay (14) over a 1-yr period in a group of IUGR infants compared to normal age-matched controls.

\section{PATIENTS AND METHODS}

A total of 21 infants (11 males and 10 females) with birth weight less than -2 SD according to Usher and McLean (15) was followed, up to the age of 12 months, with measurements of IGF 1 and TA at ages 5 days and 1, 3, 6, 9, and 12 months. The gestational age, birth weight, and birth length of the 21 IUGR infants are shown in Figure 1. The gestational age was between 37 and 41 wk in 17 children, and 35-36 wk in four children. The average birth weight was $2090 \pm$ SD $331 \mathrm{~g}$, less than -2 SD for term in all. The average birth length was $45.09 \pm$ SD 2.58 $\mathrm{cm}$, less than $-2 \mathrm{SD}$ for gestational age in 17 of the 21 children. The mean head circumference was $31.74 \pm$ SD $1.34 \mathrm{~cm}$, with a range of $28.5-33.7 \mathrm{~cm}$. The mean ratio of the weight $(\mathrm{kg})$ to the square value of the length (m), i.e. the nutrition index of Quetelet (16) was $10.22 \pm \mathrm{SD} 1.14$, with a range of 7.81-12.13 (normal values at age 1 month $13.93 \pm \mathrm{SD} 1.08$ in males and $13.58 \pm$ 1.07 in females). The mean ratio of the arm circumference to the head circumference, i.e. the nutrition index of Kanawati and McLaren (17), was $0.25 \pm$ SD 0.02 , not significantly different from the normal values that increase from $0.26 \pm 0.01$ at $35 \mathrm{wk}$ of gestation to $0.29 \pm 0.02$ at $40 \mathrm{wk}(18)$. The mean ratio of the head circumference $(\mathrm{cm})$ to the weight $(\mathrm{g})$ was $1.55 \pm$ SD 0.24 , with a range of $1.28-2.28$.

Among the 21 newborns, none was the product of a multiple gestation. Six of the 21 mothers had developed hypertension in the last months of pregnancy; it was mild in four cases and more severe in two cases. There was no other history or evidence of major pathology. Two of the 21 mothers were smokers. One was later suspected of drinking alcohol in excess, but this remained uncertain. Delivery was vaginal for 15 of the infants and by cesarean section for six infants. The mean weight of the placenta was $394 \pm$ SD $19 \mathrm{~g}$ in the normal range for length of gestation in all cases. Two of the placentas showed infarcted areas. The Apgar score was 9-10 in 13 newborns at $1 \mathrm{~min}$ and 9-10 in all 21 infants at $5 \mathrm{~min}$. All the babies received the same type of feeding. None suffered major pathologic events either postnatally or during the time of follow-up. 


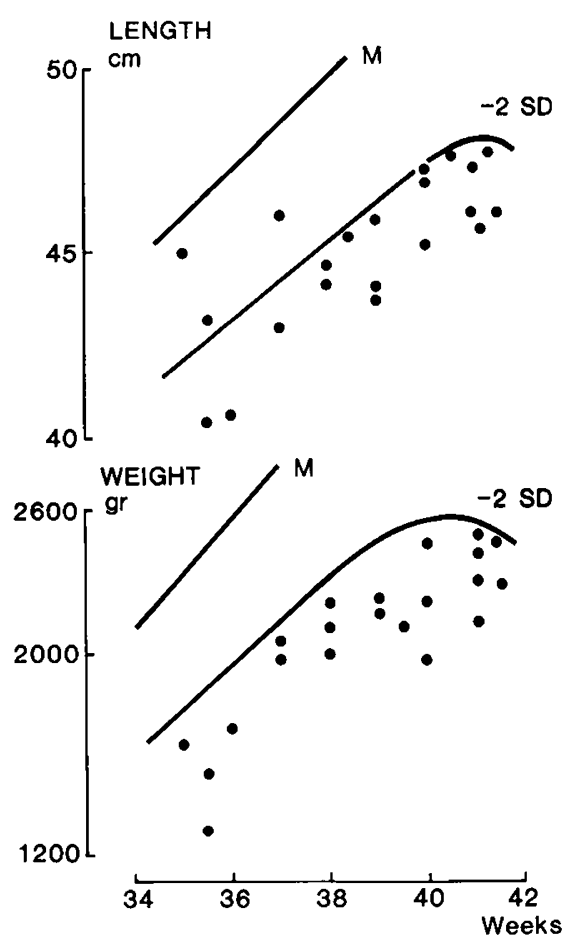

Fig. 1. Birth length and weight of the 21 patients, compared to the mean and -2 SD values from Usher and McLean (15).

Clinical examination and 2-ml blood sampling were performed at 5 days and then at $1,3,6,9$, and 12 months with the informed consent of the mother and after authorization from the ethical committee of the hospital. After $1 \mathrm{~h}$ at room temperature, serum was obtained by centrifugation and kept at $-20^{\circ} \mathrm{C}$ until laboratory assays.

Serum IGF 1 was measured by radioimmunoassay after extraction on a Sep-Pak column using kits from Immuno Nuclear Corporation (Stillwater, MN). The sensitivity of the assay was $0.05 \mathrm{U} / \mathrm{ml}$. Intraassay and interassay variations were less than $5 \%$.

The ability of serum to stimulate thymidine uptake into lectinactivated human lymphocytes incubated in vitro was measured according to the technique previously described from this laboratory (14); this result is referred to as TA.

Serum IGF 1 and TA values obtained during the longitudinal study of the 21 IUGR infants were compared with control values obtained transversely from 62 normal healthy age-matched infants subjected to blood sampling for routine examinations.

\section{RESULTS}

Clinical data. The mean length of the 21 infants at $1 \mathrm{yr}$ of age was $71.50 \pm \mathrm{SD} 3.59 \mathrm{~cm}$ and their mean weight was $8.42 \pm \mathrm{SD}$ $1.02 \mathrm{~kg}$. According to the usual French growth charts (19), eight infants (group A) had an average or above average length and weight at 12 months. The mean \pm SD length and weight for this group were $75 \pm 0.5 \mathrm{~cm}$ and $9.2 \pm 0.20 \mathrm{~kg}$. In seven other infants (group B), length and weight at 12 months were within the normal $95 \%$ confidence limits according to the charts; their mean $\pm \mathrm{SD}$ length was $72 \pm 0.24$ and weight $8.5 \pm 0.30 \mathrm{~kg}$. The six other infants (group C) were less than -2 SD at 1 yr of age, with mean $\pm S D$ length $67 \pm 1.1 \mathrm{~cm}$ and weight $7.3 \pm 0.37 \mathrm{~kg}$. The two nutrition indexes of Quetelet (16) and Kanawati and McLaren (17) did not differ significantly among the three groups. The head circumference was within the normal range for length and for weight, and did not differ significantly among the three groups.

The catch-up of growth during the first year of life, significantly better in group A (3.10 \pm 0.67 SDS) than in group B $(1.30 \pm$ 0.74 SDS $)$ or $\mathrm{C}(0.48 \pm 1.70 \mathrm{SDS})(\mathrm{p}<0.01)$, did not correlate with the head circumference or the nutrition indexes.

The height at 1 yr correlated with the midparental height ( $r=$ $0.59, p<0.02$ ) but not with birth length. However, among the three infants whose birth length was within the normal range (Fig. 1), one was in group $\mathrm{A}$, two in group $\mathrm{B}$, and none in group C.

IGF 1 and TA measurements. For IGF 1 , the mean and SEM results are shown in Fig. 2. In the controls IGF 1 increased from $0.32 \pm 0.03 \mathrm{U} / \mathrm{ml}$ at 3 days to $0.50 \pm 0.06$ at 1 month and 0.57 $\pm 0.05 \mathrm{U} / \mathrm{ml}$ at 12 months. In the three groups of IUGR infants, mean IGF 1 values at 5 days were significantly $(p<0.001)$ lower than in control infants: $0.17 \pm 0.02$ in group $A$ and $0.16 \pm 0.02$ in group $\mathrm{B}$ and $\mathrm{C}$. The mean values increased slowly in groups $A$ and $B$ to reach the control values at age 9 and 12 months, respectively, whereas in group $C$ it remained subnormal $(0.31 \pm$ $0.03 \mathrm{U} / \mathrm{ml})$ at age 12 months $(p<0.02$ comparing group $C$ with groups $\mathrm{A}$ and $\mathrm{B}$ or controls). No correlation was found between the IGF 1 values at ages 1,3 , and 6 months and the increase of length during the first postnatal year.

For TA measurements, the mean and SEM results are shown in Fig. 3. In controls the mean TA value decreased from $1.33 \pm$ $0.07 \mathrm{U} / \mathrm{ml}$ at 5 days to $1.01 \pm 0.05$ at 12 months. In the three

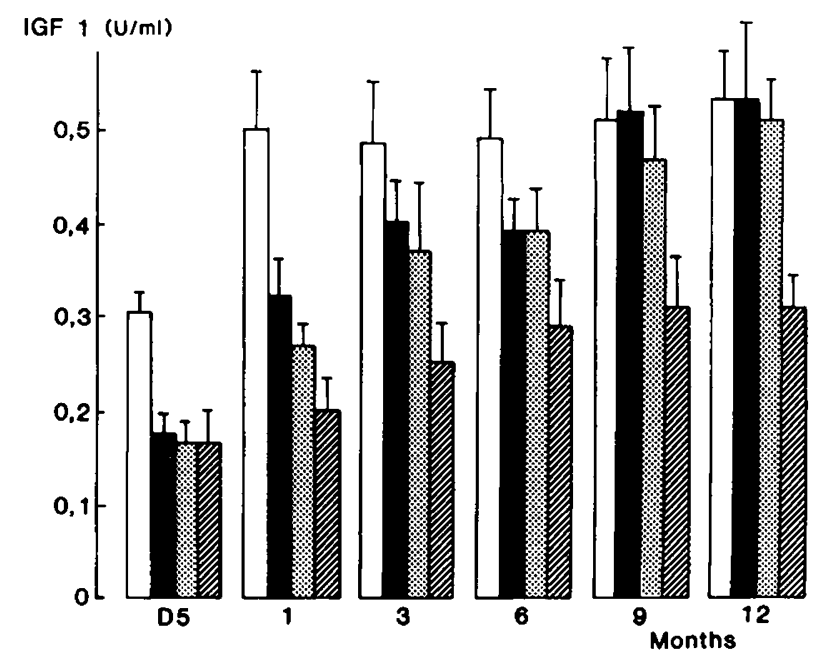

Fig. 2. Somatomedin C/IGF 1 mean and SEM values from 5 days to 12 months in controls (open bars), group A (closed bars), group B (dotted bars), and group C (hatched bars) IUGR patients.

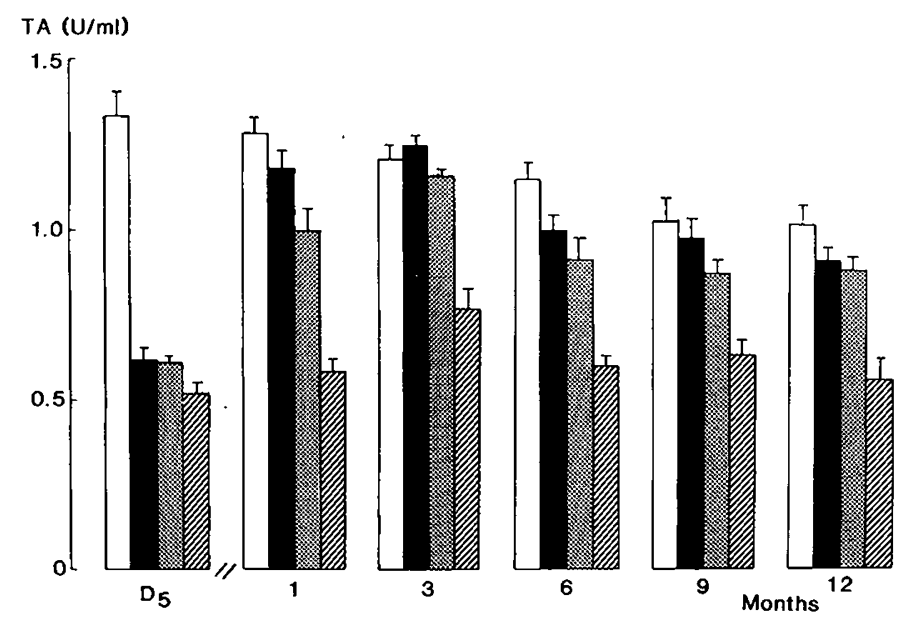

Fig. 3. Thymidine activity mean and SEM values: symbols are the same as in Figure 2. 


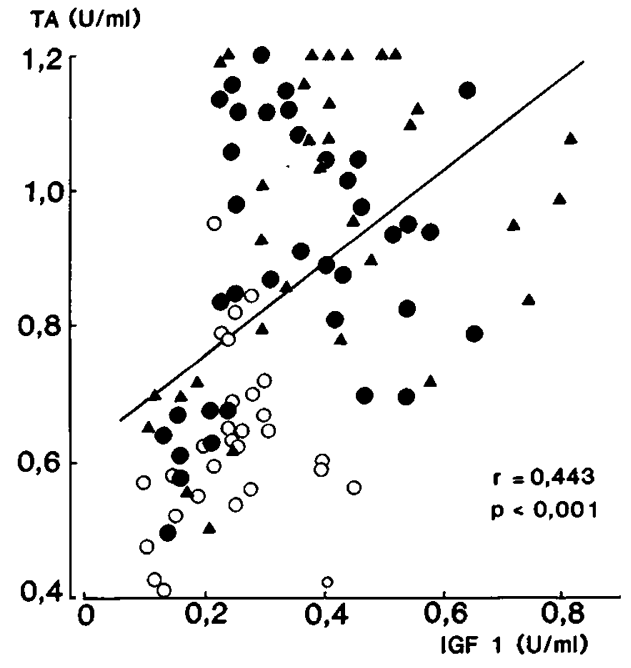

Fig. 4. Individual values and positive correlation between thymidine activity and IGF 1 in 21 IUGR children age 5 days to 12 months. Group $\mathrm{A}$; open triangles; group $\mathrm{B}$; closed circles; and group $\mathrm{C}$; open circles.

groups of IUGR infants the mean TA values were significantly $(p<0.001)$ less than the control values at age 5 days: $0.62 \pm$ 0.01 in group $A, 0.61 \pm 0.02$ in group $B$ and $0.54 \pm 0.03 \mathrm{U} / \mathrm{ml}$ in group $C$. The mean values subsequently increased sharply in groups A and B, group A reaching the mean values of controls from age 1 month and group $B$ from age 3 months; in group $C$ the mean TA level remained subnormal $(0.56 \pm 0.06 \mathrm{U} / \mathrm{ml})$ at 1 yr of age $(p<0.001$ comparing group $C$ with groups $A$ and $B$ or controls). A significant correlation $(p<0.05)$ was found between the TA levels at 1 and 3 months and the increase of length during the first postnatal year.

Individual values of IGF 1 and TA in the 21 patients are shown on Figure 4. They are significantly correlated: $r=0.443$, $p<0.001$. Studying separately the three groups of infants the correlation was significant within the group A $(r=0.349, p<$ 0.05 ) but not within groups B or C. It must be noted that in each of these groups there are only six to seven patients.

\section{DISCUSSION}

There have been several longitudinal studies of the growth of infants born with IUGR of various causes. They demonstrate that catch-up growth occurs mainly during the first 6 to 9 postnatal months $(5,9)$. SFD premature newborns have a better catch-up than SFD term newborns (1), and catch-up is better in those IUGR infants whose ultrasonographically measured cranial diameter had increased normally up to the 34th wk of pregnancy $(4,5)$. A recent study comparing the height and weight at 5 yr with the length and weight at birth in 74 IUGR children and 148 controls showed that the height at $5 \mathrm{yr}$ was significantly correlated with birth length in the IUGR children, but not in the controls (20), although there was a significant correlation between the height at $5 \mathrm{yr}$ and the parental height in the controls but not in the IUGR infants. On the contrary, in the present series, the height at 1 yr was correlated with midparental height. In the 21 IUGR newborns of the present study, the degree of catch-up in length did not relate to either the nutritional status at age $1 \mathrm{yr}$ evaluated by the weight/square of length index and the arm/ head circumferences index, or to the head circumference itself.

Human fetal IGF levels have been studied by several groups. Sara et al. $(21,22)$ first identified a fetal somatomedin with characteristics different from those of adult IGF and more recently showed, using a fetal brain membrane radioreceptor assay, that circulating IGF levels of human fetuses between 16 and 28 wk of gestation include two components: IGF 2, and a "trun- cated" variant of IGF 1 (23). Although IGF are present in fetal plasma (24), it is likely that they are less important than tissue levels of growth factors (25). Insulin and related peptides (26) and probably other factors (27) also may contribute to the regulation of fetal growth. In a previous study from this laboratory we showed that fetal IGF 1 significantly increases between $21-24$ and $25-28$ wk from $0.05 \pm 0.06$ to $0.24 \pm 0.03 \mathrm{U} / \mathrm{ml}$, whereas TA significantly decreases from $1.41 \pm 0.15$ to $0.95 \pm$ $0.05 \mathrm{U} / \mathrm{ml}(28)$. In another study comparing sera from normal and hypotrophic fetuses at midpregnancy, i.e. 19 to $24 \mathrm{wk}$, we showed a significantly lower bioassayable TA in hypotrophic $(0.84 \pm \mathrm{SEM} 0.04 \mathrm{U} / \mathrm{ml})$ than in normal fetuses $(1.28 \pm 0.09$ $\mathrm{U} / \mathrm{ml}$ ) (29\%), the TA levels decreasing from 19-22 to 23-24 wk in the normal but not in the hypotrophic fetuses.

Serum somatomedin levels in newborn infants have been reported to be low if measured by bioassay $(10,11,13)$, radioreceptor assay, or radioimmunoassay. Comparison of SGA with AGA neonates between the 4th and the 8th days of life has shown lower somatomedin bioassayable activity in SGA infants and absence of the postnatal increase that usually occurs in AGA controls (13). In one study from this laboratory (12) we showed that the cord blood of SGA newborns contains significantly less radioimmunoassayable IGF 1 than AGA control samples $(0.31$ \pm SEM 0.03 versus $0.52 \pm 0.03)$ as well as less TA (1.03 \pm SEM 0.11 versus $1.50 \pm 0.07$ ).

Another study of TA (30) showed lower values in SGA $(0.91$ \pm SD 0.11) than in AGA neonates $(1.23 \pm$ SD 0.60$)$ in capillary blood obtained during the first $6 \mathrm{~h}$ after delivery. During the next $3 \mathrm{wk}$ there was a significant increase of TA in the SGA compared with the AGA controls for whom TA remained unchanged. There was a strong positive correlation between TA and birth weight in the term SGA and preterm newborns, but not in the term newborns with normal weight.

The postnatal data reported here suggest that both IGF 1 and TA are important for catch-up growth in IUGR infants. Both activities are significantly lower in IUGR than in controls at age 5 days, then rise in those IUGR infants who have more or less complete catch-up growth during their first year of life. There is little if any rise in infants whose length remains less than $-2 \mathrm{SD}$ at ages 6 and 12 months. It may be pointed out that the postnatal rise of TA is earlier and sharper than that of IGF 1 , and that there is a significant positive correlation between the catch-up of growth and the TA values at 1 and 3 months. This correlation may be considered in the study of the postnatal catch-up growth occurring after IUGR. In the children of this study, the fact that IGF 1 levels at 1 and 3 months did not correlate with the increase in length may be of physiologic significance although the lower IGF 1 levels in the infants of group C might in some way reflect their poor postnatal growth. Further studies of the regulatory mechanisms controlling postnatal catch-up growth in SGA infants will be necessary for determining guidelines in the obstetrical and pediatric management of fetal growth retardation.

\section{REFERENCES}

1. Babson SG 1970 Growth of low birthweight infants. J Pediatr 77:11-18

2. Fitzhardinge PM, Steven EM 1972 The small-for-date infant. Later growth patterns. Pediatrics 49:671-681

3. Cruise MO 1973 A longitudinal study of the growth of low birthweight infants. I: velocity and distance growth, birth to 3 years. Pediatrics 51:620-628

4. Fancourt R, Campbell S, Harvey D, Norman AP 1976 Follow-up studies of small-for-date babies. Br Med J 1:1435-1437

5. Commery JO, Fitzhardinge PM 1979 Handicap in the preterm small for gestational age infant. J Pediatr 94:779-786

6. Woods DL, Malan AF, Hease HV 1979 Patterns of retarded fetal growth. Early Hum Dev 3:257-262

7. Davies DP 1981 Growth of small-for-dates babies. Early Hum Dev 5:95-105

8. Ounsted M, Moar V, Scott A 1982 Growth in the first four years. Diversity within groups of small-for-dates and large-for-dates babies. Early Hum Dev 7:29-39

9. Bhargava SK, Kumari S, Chaudhury P 1984 Outcome of low birthweight infants. Acta Paediatr Scand 73:406-407

10. Gluckman PD, Brinsmead MW 1976 Somatomedin in cord blood: relationship to gestational age and birth size. J Clin Endocrinol Metab 43:1378-1381 
11. Foley TP, De Philipp R, Perricelli A, Miller A 1980 Low somatomedin activity in cord serum from infants with intrauterine growth retardation. $J$ Pediatr 96:605-610

12. Thiériot-Prévost G, Daffos F, Forestier F 1985 Serum somatomedin C and bioassayable growth-promoting activity (thymidine activity) in appropriate and small-for-gestational age human newborns. Acta Endocrinol (Copenh) 110:32-35

13. Tato L, Dal Moro A, Piemonte G, Veigi G, Pizzo P, Volpato S, Gaburro D 1981 A longitudinal study of plasma somatomedin activity in full-term preterm and small-for-gestational age newborns. Biol Neonate 39:160-164

14. Thiériot-Prévost G, Schimpff RM 1981 A hormonally controlled serum factor stimulating the thymidine uptake into lectin-activated lymphocytes. Acta Endocrinol (Copenh) 98:358-363

15. Usher R, McLean F 1969 Intrauterine growth of liveborn caucasian infants at sea level. Standard obtained from measurements of infants born between 25 and 44 weeks of gestation. J Pediatr 74:901-910.

16. Rolland-Cachera MF, Sempé M, Guilloud-Bataille M 1982 Adiposity indices in children. Am J Clin Nutr 36:178-184

17. Kanawati AA, Mc Laren DS 1970 Assessment of marginal nutrition. Nature 228:573-575

18. Sasanow SR, Georgieff MK, Pereira GR 1986 Mid-arm circumference and mid-arm/head circumferences ratio: standard curves for anthropometric assessment of neonatal nutritional status. J Pediatr 109:311-315

19. Sempé M, Roy MP, Pedron G 1982 Auxologie, Méthodes et Séquences. Théraplix Publishers, Paris

20. Sann L, Darre E, Lasne Y, Bourgeois J, Bethenod M 1986 Effects of prematurity and dysmaturity on growth at age 5 years. J Pediatr 109:681-686
21. Sara V, Hall K, Rodeck C, Wetterberg L 1981 Human embryonic somatomedin. Proc Natl Acad Sci USA 78:3175-3179

22. Sara V, Carlsson-Skwirut C, Andersson C, Hall E, Siögren B, Holmgren A Jörnvall H 1986 Characterization of somatomedins from the human fetal brain: identification of a variant form of insulin-like growth factor I. Proc Natl Acad Sci USA 83:4904-4907

23. Carlsson-Skwirut, Andersson C, Sara V 1987 Circulating forms of human fetal somatomedin. Acta Endocrinol (Copenh) 114:37-40

24. Ashton IK, Zapf J, Einschenk I, Mac Kenzie IZ 1985 Insulin-like growth factors 1 and 2 in human fetal plasma and relationship to gestational age and fetal size during mid-pregnancy. Acta Endocrinol (Copenh) 110:558563

25. Han VKM, Hill DJ, Strain AJ, Towle AC, Lauder JM, Underwood LE, D'Ercole AJ 1987 Identification of somatomedin/insulin-like growth factor immunoreactive cells in the human fetus. Pediatr Res 22:245-249

26. Milner RDG, Hill DJ 1984 Fetal growth control: the role of insulin and related peptides. Clin Endocrinol 21:415-433

27. Johnson DJ 1985 Regulation of fetal growth. Pediatr Res 19:738-741

28. Thiériot-Prévost G, Daffos F, Forestier F, Job JC 1986 Serum somatomedin $\mathrm{C}$, bioassayable growth-promoting activity (thymidine activity) and transferrin in human fetuses: in utero study. Pediatr Res 20:71-73

29. Thiériot-Prévost G, Daffos F, Forestier F, Chartier M, Job JC 1987 Serum growth-promoting activity in normal and hypotrophic fetuses at midpregnancy. Pediatr Res 22:39-40

30. Bozzola M, Chirico G, Chiara A, Gasparoni A, Schimpff RM 1985 Serum growth-promoting activity in human newborns. Acta Paediatr Scand 74:534538 